\title{
THE "PROBLEM OF VALUES" AND INTERNATIONAL RELATIONS SCHOLARSHIP: FROM APPLIED REFLEXIVITY TO REFLEXIVISM
}

\author{
Inanna Hamati-Ataya \\ International Studies Review 13(2): 259-287. 2011.
}

\begin{abstract}
In light of recent discussions of cognitive and ethical dilemmas related to International Relations (IR) scholarship, this paper proposes to engage the "problem of values" in IR as a composite question whose cognitive treatment requires the objectivation of the more profoundly institutional and social processes that subtend its emergence and evolution within the discipline. This analysis is hereby offered as an exercise in reflexive scholarship. Insofar as the question of values constitutes a defining cognitive and moral concern for reflexive knowledge itself, the paper also points to the need for its reformulation within an epistemic framework that is capable of moving beyond reflexivity to Reflexivism proper, understood as a systematic socio-cognitive practice of reflexivity.
\end{abstract}

\section{INTRODUCTION}

International Relations (IR) scholarship finds itself today in a situation that is reminiscent of the one in which Max Weber (2004[1918/1919]) found the German academy a century ago, with no clear standards for the definition of the scholar's relationship to the public sphere, and of scholarship's social and moral role". The International Studies Association's (ISA) 2007 Annual Meeting, which called on the IR community to reflect on issues of "political involvement," "scientific detachment," "moral responsibility," and "ethical standards" (Tickner and Tsygankov 2008:661) is the institutional manifestation of this current state of affairs, which has recently been questioned or rejected by scholars promoting a more "reflexive" engagement with the commitments that underlie or result from IR's objectivation of world politics (Smith 2002 and 2004; Agathangelou and Ling 2004; Widmaier 2004; Tickner 2006; Lynch 2008; Ackerly and True 2008; Ish-Shalom 2008). "September 11" and the subsequent US "war on terror" have undoubtedly provided an extra-ordinary context and material for a critical reflexion on the discipline's conceptual and practical relationship to its object of study, especially in light of the promotion of the Democratic-Peace thesis to the rank of official state ideology (Steele 2007; IshShalom 2008). The problems that the ISA organizers submitted to their colleagues' consideration are, however, neither new, nor specific to IR.

The status and role of values in knowledge have indeed constituted a central theme of Western epistemology and its defining principle of objectivity. Not only were they constitutive for the birth of the social sciences, but also repeatedly revisited with every new paradigmatic shift and social concern individually affecting them. IR has in this respect been no exception: the

I would like to thank Michael C. Williams and the three referees who reviewed this paper, for their detailed and thoughtful comments, criticisms and suggestions. 
"problem of values" is inscribed in most of its disciplinary debates, and the properly moral dilemmas that IR scholarship faces today have been equally - if not more violently - present in its disciplinary past. Some may dismiss them as marginal. For those of us who are convinced that these issues are central to both our cognitive endeavor and scholarly ethos as knowledgeproducers and social agents, it is legitimate to ask whether our treatment of these questions has led us anywhere closer to a satisfactory understanding and resolution of the problems and dilemmas they impose on us. "Dissident" IR scholarship has, after all, expressed itself in the past with great relevance and some degree of efficiency. Yet we find ourselves today struggling again with the same issues. To what extent, then, is the "Iraq War" different from the "Vietnam War" as a defining moment for IR scholarship, and why should we expect contemporary "dissidents" to be more successful than their predecessors in significantly altering IR's intellectual and social practice? This paper posits that no significant progress can be made on these issues if we do not attempt to deconstruct the dominant culture of Positivism and its peculiar perspective on the "problem of values," and to subsequently offer an alternative that is both cognitively more sound, and socially and morally more useful for the definition of our relationship to the social world.

From this perspective, before actually attempting to answer the questions that were asked at the 2007 ISA Meeting, one needs first to ask how we got "here," and what this "here" represents, cognitively and socio-historically, for IR. The process of deconstructing the "problem of values" therefore requires the adoption of a dual, reflexive methodology, whereby IR's discourse on values is subjected to a meta-theoretical analysis that aims to make explicit its underlying epistemic premises, and to a sociological analysis that aims to identify the exogenous factors that have given such premises a measure of cognitive relevance. In other words, the terms of the debate over the fact/value dichotomy, the nature/status of values, norms, objectivity or value-freedom are premises that are hereby questioned not merely through the use of logic and philosophy, but through a socio-analysis that objectivates their social significance and origins. This paper, then, is guided by the idea that the way the "problem of values" has been framed, formulated, treated, or avoided in IR is the result of a complex socio-intellectual process rather than a purely rational one governed by logic and the rationale of science. "Why do we think the way we do today about values?" and "Why do we think of values as a problem?" thus become a legitimate starting point for a reflexive analysis.

However, since the purpose of reflexive knowledge is also to permit the production of a more realistic and praxis-bearing understanding of how knowledge and reality are mutually constitutive (Guzzini 2000; 2005), and since the question of values is at the heart of the reflexive problématique (Hamati-Ataya 2010), such a reflexive viewpoint should also provide us with the means to alter cognitive and scholarly practice itself. The attempt to "institutionalise reflexivity" (Guillaume 2002: $\$ 33$ ) should therefore be made. I suggest that this entails moving beyond reflexivity as a given conceptualization of the relationship between knowledge and reality, to Reflexivism proper, understood as a research program that is grounded in reflexivity and that presents itself as an alternative to Positivism. This paper therefore has two simultaneous objectives. On the one hand, the content of its two parts aims to achieve, respectively, a deconstruction of the "problem of values" in IR and then its reconstruction on the basis of an alternative cognitive and deontological perspective. On the other hand, its structure aims to make explicit the articulation of methodology and content, i.e., how a reflexive understanding of $\mathrm{IR} /$ politics can lead to a Reflexivist knowledge and praxis. 
The first part of the paper, then, presents the "physiology" of the question of values in IR understood as a composite socio-intellectual one, whose cognitive, institutional, and social dimensions are dynamically intertwined in such a way that different stakes are involved and corelated in IR discussions of the problem and of its alleged resolution, as well as in the discipline's silence(s) about it. I start with the idea that the purely cognitive treatment of the "problem of values" is governed by the logical relationship among three questions pertaining respectively to the nature of (a knowledge of) values, the relationship between the factual and the normative, and the nature of objectivity understood as value-freedom. These questions are paradoxically both organically related to, and disjoined from, one another. Their disjunction has allowed a disciplinary shift from cognitive standards and concerns to socio-institutional ones.

More specifically, I argue that with the emergence of the culture of Positivism within IR and its underlying institutional and social interests, the question of how values can, given their proper nature, be studied has been progressively and implicitly replaced with how, given the nature of science, they could be excluded. This intellectual displacement of the terms of the debate corresponds to "value-freedom" being given precedence, and sometimes even exclusive attention, over the other two cognitive concerns. This Positivist moment has consequently operated, or at least allowed, another significant shift from an original concern with the relation of academic to public discourse, to a general disengagement from scholarship's moral role. I then argue that this has by and large been sustained, to date, by a disciplinary consensus over the purpose of theory, with the transformation of the analytical distinction between "problemsolving" and "critical" or "reflective theory" into a properly institutional one, whereby different communities of IR scholars co-exist in such a way that the problem of values ceases to embody a universal philosophical, epistemic and moral issue, and becomes restricted to the research questions and concerns generated exclusively by a specific type of IR, namely the "critical," "reflective" type.

In light of this analysis, the second part of the paper aims to reformulate the question of values precisely as a composite one whose treatment necessitates the production of a discourse that is capable of acknowledging the relationship between cognitive, institutional and social processes, and of objectivating this relationship within a single theoretical frame of reference. I suggest that such an endeavor can be achieved within a Reflexivist IR, where Reflexivism is defined as a systematic socio-cognitive practice of reflexivity, and reflexivity as the scholar's conceptual/methodological response to her acknowledgment of the mutual reflectivity of knowledge and reality, i.e., of the inscription of social divisions, interests and concerns in cognitive categories of understanding and analysis, and vice versa.

Because it is itself grounded in a commitment to reflexivity as a requirement and prerequisite of IR scholarship, the second part of the paper departs from the second-order analysis of the first part, and establishes itself firmly in a non-foundationalist epistemic position that aims to reverse the cognitive and ethical tenets of Positivism. At the cognitive level, Reflexivism frames the question of values independently of the dichotomies and problematique Positivism has imposed on scholarship for decades, by identifying the importance of acknowledging and exploring the relationship between "being" and the historical potentialities that it can generate, and that between knowledge and judgment/praxis. This enables Reflexivism to engage the ethical/social dimension of knowledge by reversing the Positivist deontology of value-freedom, while transcending the Weberian ideal-typical approach to scholarly ethos. 


\section{EMBRACING THE PROBLEM OF VALUES IN IR: THE PHYSIOLOGY OF A COMPOSITE SOCIO-INTELLECTUAL QUESTION}

The history and sociology of science have de-sacralized the standards and beliefs that govern the activity of scientists as individuals and as organized communities, including the notions of "truth" and "objectivity," by revealing the social and ideological mechanisms and stakes that underlie scientific debates and the emergence or disappearance of concepts, theories, and forms of knowledge throughout history. All debates pertaining to the nature and criteria of scientific objectivity, such as the "problem of values," can be approached from a sociological perspective, in order to identify the particular structures and processes (material and ideational) that subtend them, and that contribute to the social/institutional fixation of the criteria and categories that define and guarantee their intellectual legitimacy (Bourdieu 1984 and 1998[1992]). A deconstruction of the "problem of values" in IR should therefore attempt to reconstruct the link between cognitive consensus and socio-historical constraints.

\section{Where we stand today: IR scholarship's moral dilemma}

The moral dilemmas that IR faces today are empirically revealed by its scholars' attitude toward the public sphere. The positions currently taken by IR scholars not only signify the antagonisms that exist within the discipline, but also point to the importance of IR's sociopolitical context in shaping its scholarly discourse on the relation of knowledge to values. Two particular positions are worth noting here, because they represent two ideal-typically different reactions, but can also simultaneously be viewed as the two sides of a single coin.

The first position is exemplified in a statement published in the New York Times in September 2002 by a group of 33 IR scholars (Art et al. 2002), in which they express their opposition to the impending US-led military operation against Iraq - an early manifestation of what, four years later, is the silently shared view of $76 \%$ of American IR scholars (Maliniak et al. 2006). Based on a strict rationalization of US "national interest" in light of the lack of "material" evidence justifying the operation and the equally "material" negative consequences for the US that said operation would lead to, the statement can be read as a minimalist, realist "policy science" utterance (Hoffmann 1960:10). In this short text, the signees have implicitly but clearly revealed a great part of their scholarly ethos and their position vis-à-vis their object of study: the statement indeed reveals that what their intellectual stand targets is only the most factual, material manifestations of politics. The statement does not touch upon the axiological/normative principles that underlie US foreign policy, such as the hidden justifications for the "war," nor its moral aspects or consequences. In other words, it is clearly governed by a double non-dit or unspoken principle, namely, that academic discourse is limited to addressing a certain aspect of reality, and that its intervention in the public sphere is acceptable/legitimate insofar as it respects the rules of "neutrality" that are defined by this limitation.

The second position is exemplified in Steve Smith's 2003 Presidential Address to the ISA, powerfully entitled "Singing Our World into Existence: International Relations Theory and September 11" (Smith 2004). Written "on the eve of a probable war against Iraq" and published after its launch, the paper aims to "raise explicitly the relationship between academic study and ethics". More specifically, it claims "that the discipline of International Relations is complicit in the constitution of this world of international relations," that "there can be no such thing as a 
value-free, non-normative social science" and that "the ways in which the discipline [...] constructs the categories of thought within which we explain the world, helps to reinforce Western, predominantly U.S., practices of statecraft that themselves reflect an underlying set of social forces". This, the author admits, "is unavoidably an ethical issue, and to be clear from the outset I do not see any possibility (or desirability) of separating ethics from academic study" (Smith 2004:498-500).

These two texts are manifestations of two different academic positions, as well as the joint expression of the deep divide that currently structures IR scholarship with respect to how it conceives of the nature of its intellectual and social practice, and the terms of its social and moral dilemmas. They can, however, simultaneously be viewed as the manifestation of the same phenomenon, namely, the present state of a discipline that "ha[s] ignored, to its cost, ethical questions in the pursuit of value-neutral explanations" (Smith 2004:513). Smith's reflexive attempt to deal with this state of affair, in the form of a collective mea culpa that calls for a revision of the discipline's central cognitive tenets, is merely the mirror image of the 33 IR scholars' self-restrained public manifesto. The question, then, is how did we get to this point? How did we get "here"? Surely, IR scholarship did not "ignore ethical questions" because of some cognitive necessity or some intrinsic impossibility of addressing them theoretically. I would like to argue, rather, that this situation has its roots in the rise in importance of a properly social concern that played a determining role in segregating the question of value-freedom, understood as the corollary of scientific objectivity, from the full problematization of the question of values.

\section{From value-freedom to moral disengagement:}

The social embeddedness of the cognitive debate on values

The problem of value-freedom, value-neutrality or ethical neutrality (and these terminological differences are important - see below), is intimately related to two other complex problems. The first one pertains to the nature of values (often conceptualized as different from "facts") and therefore to the possibility of producing an objective knowledge of them (as opposed to "value-judgments"). This is one of the oldest and most recurrent themes of philosophy, ethics, and the philosophy of knowledge, and the opposite epistemic positions of value-cognitivism and value-non-cognitivism each have their proponents in this endless debate (see Hobbes 1994[1651]; Durkheim 1953[1911] and 1966[1895]; Weber 1949a[1917] and 1949b[1904]; Brecht 1959; Taylor 1967; Oppenheim 1973). The second problem pertains to the relationship between the factual/descriptive and the normative/prescriptive, and therefore to the differences and relationship between scientific and ideological discourse, and more generally between science and politics/ethics. Often framed in terms of the dichotomy between what is and what ought to be, this second problem touches upon epistemological, deontological and moral issues alike (see Hume 2003[1739-40] and 1983[1751]; Comte (1880); Marx and Engels 1978[1845]; Durkheim 1966[1895]; Weber 1949a[1917]; 1949b[1904] and 2004[1918/1919]; Hare 2003[1952]; Searle 1969; Mackie 1977). I distinguish these different questions in order to highlight the following, important paradox: that they are organically related to, but also disjoined from, one another.

They are organically related in the sense that the way wherein one problematizes and answers one of them will logically affect, and possibly determine, how the others are problematized and answered. For example, a philosophy of knowledge that considers that values 
cannot be objectively known (value-non-cognitivism) may consequently consider that the discovery of facts cannot further our understanding of norms, and that science can therefore not shape policy; this may lead to an ethos of moral neutrality whereby the scholar, by acknowledging her lack of competence over axiological and normative issues, will refrain from dealing with all types of values and norms altogether. On the other hand, a philosophy of knowledge that considers that an objective knowledge of values is possible (value-cognitivism) may consequently consider that social science is capable of revealing causal relations between given social structures and the achievement of given political norms; this, in turn, would allow the scholar to position herself within an activist perspective wherein her discourse is made relevant to public debates and policies, and therefore enable her to actually express preferences for given social norms. There are of course too many possible variations to discuss them all here, but it is worth noting three things. Firstly, that the consistency of a given theoretical position with respect to the "problem of values" can be assessed in light of the logical consistency among the answers to these three questionsi ; secondly, that any attempt by IR scholarship to rigorously and systematically address the question of value-freedom will necessarily require it to address the other two problems as well; finally, that the very terms in which these questions have been posed - and their answers formulated - in Western philosophy are grounded in a particular premise that often enjoys the status of a universal a priori, namely, the "fact-value dichotomy".

Paradoxically, these three questions are also disjoined in the sense that they can individually be made relevant to different and independent practical concerns. This is already suggested in the fact that despite their organic relationship, there is no necessary intellectual requirement as to which question should be addressed first, and the scholar may just as well be motivated by epistemic choices that subsequently produce ontological and methodological ones, as she can be motivated primarily by practical methodological or empirical concerns that will determine the extent to which she will need to bother about epistemic, ontological or ethical consistency. Within the predominant empiricist IR scholarship, it is not even certain that these issues will be given any significant importance at all. If they are nonetheless considered, which question will be addressed first, or perhaps even exclusively, may also often be determined by non-cognitive concerns or commitments. For example, Smith's recent $(2002 ; 2004)$ primary preoccupation with "value-neutrality," rather than the ontological status of values or the epistemological debate over the nature of objective knowledge, is directly motivated by a social/moral concern that was triggered by a specific historical situation ${ }^{\mathrm{ii}}$. The social, ideological, or properly ethical considerations that motivate or orient scholarship are therefore likely to influence theoretical commitments and choices at least as much as the requirements of theoretical consistency.

Regardless, then, of the logical constraints that govern any comprehensive treatment of the problem of values, the actual historical treatment of this problem, in most of Western/American political and international theory, has been partial in the sense that the question of value-freedom has constituted both a disproportionately important concern and a disproportionately important standard for theoretical and empirical production. This phenomenon is clearly illustrated, in the case of American scholarship, in the significant transformation of the Weberian intellectual position and the ethos it defines. Weber's analysis one of the most consistent treatments of the problem of values - was adopted by American social scientists in the early days of the establishment of American political theory (Gunnell 1993; 2006). It has, however, undergone a serious transformation with the emergence of the Behavioral Revolution and the culture of Positivism, whose impact on IR are still felt today. 
Weber used the term Wertfreiheit to refer to the requirement that the scholar keep unconditionally separate the establishment of empirical facts (including the "valueoriented" conduct of the empirical individual whom he is investigating) and his own practical evaluations, i.e., his evaluation of these facts as satisfactory or unsatisfactory (including among these facts evaluations made by the empirical persons who are the objects of investigation) (Weber 1949a[1917]:11; emphasis in original).

Most of the tenets of Weber's Verstehen (or "interpretive") sociology are included in this statement. The two parenthetical propositions refer to Weber's ontological position, which considers that values underlie human conduct, and that they constitute the social scientist's object of study. That he views them as "included" in "empirical facts" means that although he utilizes the analytical distinction between "facts" and "values" (rather than the fact/value dichotomy), he does not consider that this distinction is sufficient to exclude values from the inquiry of social science, and that values can and should be objectivated as particular types of facts. The reason why the "establishment of empirical facts" should be "kept unconditionally separate" from value-judgments is that "to judge the validity of [...] values is a matter of faith," and the adherence to given "ultimate standards is [a] personal affair" that "involves will and conscience, not empirical knowledge" (1949b[1904]:55, 54). "Ultimate standards" or norms can therefore not be logically deduced from factual knowledge. The resulting dichotomy between empirical and normative discourse provides the foundation for sociology as a science concerned with the "analysis of facts" and the discovery of objective causal relations, a science incapable of supporting the axiological claims of social agents. While sociology can study human valuations empirically, it cannot, however, prove that some valuations are superior to others, and can therefore provide no guidance for the establishment of socio-political norms, because "the validity of a practical imperative as a norm and the truth-value of an empirical proposition are absolutely heterogeneous in character" (Weber 1949a[1917]:12). Consequently, the "analysis of facts" cannot lead to "statements of ideals," which is the proper realm of social policy (Weber 1949b[1904]:60).

This logical dichotomy, in turn, produces another, deontological one that segregates the realm and ethos of "scientific man" from those of "political man" (Weber 2004[1918/1919]). From the Weberian perspective, scientific knowledge produces a rational, not an axiological obligation, since "strictly and exclusively empirical analysis can provide a solution only where it is a question of means adequate to the realization of an absolutely unambiguous end" (1949a[1917]:26). By revealing the causal relations that account for social phenomena, science implicitly delimits the realm of rational action in a hypothetical, not categorical manner. In this sense, "it cannot tell anyone what he should do - but rather what he can do" (1949b[1904]:54) without, however, guaranteeing that he will, for the laws of human behavior, unlike those of nature, are ultimately governed by freedom. Wertfreiheit, then, means that the scholar should remain "free from" the preferences and objectives of political agents, and be exclusively guided by her own ethos, which guarantees, if not that political agents will listen to her, at least that her social role is endowed with enough legitimacy for her to maintain an independence from the agenda of political agents, as well as the possibility of confronting their policies with an autonomous knowledge whose standards are independent of individual and social preferences and interests. Weberian value-freedom, then, essentially implies an ethos of social responsibility, rather than one of detachment or disengagement. 
Weber's problematization of the question of values is itself embedded in a sociohistorical singularity, that of the German academy's relationship to the public and political spheres in a specific moment of its history. Although this socio-historical embeddedness constitutes an important boundary condition for the relevance of his analysis to other sociohistorical contexts, it has gained significance in American scholarship precisely because of the similarities of the socio-intellectual dilemmas that American political scientists were faced with during the constitutive period of American social sciences, as well as the parametric role the German model played in the establishment of American Political Science (Gunnell 1993; Somit and Tanenhaus 1967). However, with the evolution of the American academy and of its underlying institutional and social concerns, the cognitive rationale and ethos of the Weberian position have been significantly transformed. The concern for value-freedom has become more intimately tied to the social legitimacy and credibility of the social sciences than to a properly cognitive and ethical investigation. With science being allocated an increased social value in Western societies (especially in the US), the principles of objectivity, rationality, and scientific rigor have become increasingly instrumental in shaping the social sciences and their social agenda. This led to value-freedom being understood as a methodological standard that could be achieved through techniques of value-control, independently of an investigation of their meaning in orienting the scholar's research and epistemic choices. The purpose became to pursue "objectively controlled inquiry" (Nagel 1979[1961]:486-7) by guaranteeing that values are not allowed "a role that insulates them from the test of experience" (Abraham Kaplan, quoted in Greene 1970:289) $)^{\text {iii }}$. The more problematic aspects of scholarship's relation to values have consequently been "prudently tabled in the interest of getting on with empirical research" (Searing 1970:71).

This shift from cognitive to praxeological concerns is manifested in one of the founding texts of American Behavioralism, David Easton's The Political System. Easton (1953:221) characteristically utilizes the Weberian epistemic stance, when he declares that

[a]lthough in practice no one proposition need express either a pure fact or a pure value, facts and values are logically heterogeneous. The factual aspect of a proposition refers to a part of reality; hence it can be tested by reference to facts. In this way we check its truth. The moral aspect of a proposition, however, expresses only the emotional response of an individual to a state of real or presumed facts. It indicates whether and the extent to which an individual desires a particular state of affairs to exist. Although we can say that the aspect of a proposition referring to a fact can be true or false, it is meaningless to characterize the value aspect of a proposition in this way. (emphasis added)

However, Easton's position is now inscribed in a different rationale, and in a different sociohistorical and institutional moment. With Behavioralism, the priority is no longer so much to defend value-freedom in order to prevent the collusion with power and maintain the type of intellectual independence that would allow the practice of an ethos of social responsibility, but to herald it as the corollary of the type of scientific objectivity that is equated with "rigor" and "efficiency" (Eulau 1969; McCoy and Playford 1967). For Easton, the "malaise" in which American Political Science finds itself in the 1950s results not from the social and moral dilemmas that accompany its students' proximity to their object of study, but from their lack of understanding of science, and lack of will in the acquisition of the scientific attitude that other scholars have successfully adhered to and internalized, especially economists. This signifies the 
extent to which the intellectual mood had changed since the institution of American Political Science, which was now more concerned with establishing a clear break with its philosophical legacy and its corresponding ethical tradition of inquiry. As Charles Taylor (1967:25) put it,

$[\mathrm{t}]$ he view was indeed that political science has come of age in freeing itself finally of the incubus of political philosophy. No more would its scope be narrowed and its work prejudiced by some value position which operated as an initial weight holding back the whole enterprise.

This mood prevailed in (American) IR at the same time, as recorded in the literature of the heated "second debate" between those who labeled themselves the "scientists" and those they labeled the "traditionalists" (see Knorr and Rosenau 1972[1969]) ${ }^{\mathrm{iv}}$. The terminology of this debate points to the institutional and social stakes that were involved in what many commentators consider to be a purely epistemological or methodological discussion. This is first visible in the very discursive strategies used by the proponents of the "scientific" approach to delegitimize the forms of scholarship embodied by their opponents (as revealed by the accusation of "traditionalism"), by rejecting them outside of "objective" knowledge, either in the margins of the field, or properly without it, which usually meant somewhere in Philosophy or History. What appears to be a fundamentally intellectual divide (as manifested in the debate over explaining vs. understanding) can also be viewed as the rationalized, probably unconscious competition between different forms of intellectual and academic capital, with the emergence of a new generation of scholars endowed with a type of knowledge that is relevant to a more quantitative approach to social reality, and its correlated skills, such as Mathematics and computer modeling.

More importantly, the debate was subtended by exogenous stakes resulting from the newfound and rewarding interest of the political field for the increasingly scientific and reliable science of politics/IR. This imposed social and institutional constraints on the new generation of scholars, bound by the logic of public and private funding and support to engage in the newly legitimized approach to social facts (Jackson and Sørensen 2003[1999]:45), sometimes resulting in odd "conversions" among previous opponents to Positivism. Significantly, the adoption of the term "behavioral science" by a group of scholars from the University of Chicago was itself motivated by the fear that a confusion between "social science" and "socialism" would dissuade federal institutions from allocating them funds (Somit and Tanenhaus 1967:182-183).

The socio-historical underpinnings of this intellectual debate are further manifested in the fact that the culture of Positivism was strongly opposed by a different social group characterized by a different habitus (see Bourdieu 1980): a group of European émigrés including Hans Morgenthau, Hannah Arendt, Leo Strauss, Erik Voegelin and Herbert Marcuse, who shared a sensitivity for the intellectual's social role (Gunnell 2006), which became an important existential issue in light of $20^{\text {th }}$-century Europe's political experience. Among these scholars, pessimism and caution with regards to value-freedom and benevolent social engineering were accompanied by a constant reminder of the need for political and international theory to preserve its role of judge of power (Morgenthau 1946; 1958; 1970) and its corresponding engaged ethos of citizenship (Strauss 1969). However, the alignment of public and academic interests and conceptions regarding the nature and social role of political science (see Oren 2002; 2004) were instrumental in shaping the social boundaries of authorized or acceptable scholarship: when (the Weberian) Morgenthau (1965) mobilized his understanding of power politics to condemn American foreign policy in Vietnam, he found himself isolated from both the field's mainstream 
scholarship and the circles of power, which were increasingly irritated by his intrusive voice (Glaser Rafshoon 2001). Weber's idea that "only if science was distinct from politics, with separate standards of validity, could it speak with authority to politics and constitute a critical voice" was being successfully replaced with social and moral "disengagement": by the 1960s, "most behavioral political scientists had largely ceased to discuss the relationship between public and academic discourse" (Gunnell 1993: 149, 223).

The main consequence, then, of the emergence of the culture of Positivism (and scientism) in American IR, is an analytical confusion between "value-freedom" (i.e., cognitive objectivity/impartiality) and "ethical neutrality" (i.e., moral disengagement/indifference). Significantly enough, Weber's Wertfreiheit, which denotes a freedom from "what is endowed with value" (literally, worth), and which is often used in German as synonymous with Werturteilsfreiheit (freedom from value-judgments) $\mathrm{v}$ is actually translated as "ethical neutrality," rather than "value-freedom" (see Weber 1949a[1917] and 1949b[1904]); the interchangeability of the two terms in the English-speaking literature of the field is itself representative of this implicit displacement. "Ethical neutrality" implies that the problématique of values concerns moral values, and consequently that the neutrality of the scholar is one vis-à-vis morality. This suggests the extent to which the adherence to a Positivist view of objectivity would logically entail an ethos of moral disengagement. In French, however, a significant distinction between "neutralité axiologique" (value-neutrality) and "neutralité éthique" (ethical neutrality) allows for a distinction between cognitive objectivity and moral neutrality, which are thereby not viewed as mutually inclusive. This also allows for the investigation of the problem of values as $a$ particular case, rather than a corollary, of the problem of "epistemic and methodological neutrality" (see Bourdieu, Chamboredon and Passeron 1983[1968]:61-71). But in most Western (American) political and international theory, "value-freedom," "value-neutrality" and "ethical neutrality" have become synonymous, elliptical expressions, generically referring to a negative attitude toward everything axiological, with no particular need to specify what scholarship is actually supposed to be "free(d) from". The important nuances have in effect been lost in the literature.

The adherence to a notion of "value-freedom" understood as both synonymous with objectivity and a (sufficient) guarantee of objectivity has thereby led to a generally accepted and consensual stance whereby values as both objects of study and as constitutive variables in the production of knowledge are largely disregarded. The Behavioral Revolution has thus successfully turned a social division (scientists vs. non-scientists) into an analytical dichotomy (value-neutrality vs. moral engagement). As I wish to argue next, this situation has been further reinforced in IR, despite renewed opposition to it, by a second socio-intellectual process involving the question of theory's "purpose".

Keeping dissidence at the margins:

The institutionalization of analytical divisions

The displacement of the question of values and its reduction to a positivist standard of value-control have not gone unchallenged in social, political and IR theory, even during the Behavioral Revolution. Some critics saw in the Behavioralist's effort to become a "pure scientist" merely "a device for avoiding politics without achieving science" (Alfred Cobban, quoted in Hoffmann 1960:40-1). Others viewed the scientific approach as simply dangerous. Hedley Bull (1972[1966]), who saw the new trend as a specifically American one, warned that 
"by cutting [itself] off from history and philosophy" political and IR theory had "deprived [itself] of the means of self-criticism". Even Easton (1969) proposed, two decades after his original call for a scientific approach, to acknowledge the need for moral evaluation and for a new, "postbehavioralist revolution". This was merely an adjustment to a more profound division within the American academy. Behavioralism had in fact led to the rise of an internal dissidence that called for a reform of the social sciences' methodologies and underlying ethos. Militant associations emerged, such as the Radical Caucus in Sociology and the Sociology Liberation Movement (see Nicolaus 1968; 1969), the Union for Radical Political Economists, and the Caucus for a New Political Science (CNPS). The CNPS, which "was formed in 1967 to challenge the complacency of American political science, its conservatism, its government links and, above all, [...] the 'irrelevance' of the discipline," was particularly suspicious of the positivist ethos of valueneutrality and the general "sciencizing" of the field, which it viewed as "politics by other means" (Surkin and Wolfe 1970:3,4). As Marvin Surkin (1970:14) put it,

the rigorous adherence to social science methodology adopted from the natural sciences and its claim to objectivity and value neutrality function as a guise for what is in fact becoming an increasingly ideological, nonobjective role for social science knowledge in the service of the dominant institutions in American society.

It is unlikely that IR was oblivious to such social oppositions. Within its own ranks, however, the problem seems to have successfully been contained within a strictly intellectual setting. A wider and more systematic sociological investigation of the development of IR in the 1970s is needed to explain its immunity against such permeating events, but it is reasonable to hypothesize that the institutional concern for the preservation of the discipline and of its autonomy have contributed to postponing the (marginal) impact of the anti-positivist critique to the 1980s. The revival of its founding paradigm - Realism - in the form of a structural, positivist approach to world politics, is in this respect both strange and extra-ordinary in its success, since it managed to "lock up the discipline again" (Guzzini 2000: 156). Neorealism succeeded indeed in its disciplinary ambition of immunizing the old founding paradigm against the diversification of its subject-matter, and against the increasingly diffused and versatile definition of power that resulted from the inter-disciplinary research programs of Behavioralism and from the emergence of economic and cultural approaches to international relations (Brown 2005[2001]:33; Viotti and Kauppi 1987:562; Guzzini 2002[1998]:108). The properly institutional concern for disciplinary autonomy has therefore constituted an important factor in further isolating (scientific) IR from the other social sciences, and hence from the more philosophical, normative, historical and sociological approaches to world politics.

In light of this general institutional setting, an important process should be considered, which has operated a shift in the opposite direction than the one operated by the Behavioral Revolution, by transforming an analytical division into a socio-institutional one. This analytical division, which has informed IR discussions of the purpose of theory, is that between "short-run" "problem-solving theory" and "long-run" "critical theory" (Widmaier 2004:428), which has been turned into a properly institutional and intellectual dichotomy, thereby efficiently leading to the neutralization of the most challenging and de-legitimizing critiques of the latter against the former.

An early example of the problematization of theory's purpose is found in Stanley Hoffmann (1960:8), who distinguished among "normative" or "value" theory, "empirical" or 
"causal" theory, and "policy science". This "analytical" classification was proposed to highlight the many layers of purpose involved in the objectivation of politics - respectively, philosophical inquiry, theoretical explanation, and social change - with the complementary warning that the actual segregation of purely scientific theory from normative theory should be avoided (1960:173-4). The rise of anti-positivism in IR further contributed to bringing these differences to the forefront of scholarly debates. IR's "third debate" (Lapid 1989) has in fact helped institutionalize these differences in the form of a dichotomy between "problem-solving theory," associated with Neorealism, Neoliberalism and Rational Choice Theory, and "critical theory," associated with post-positivist approaches such as Neomarxism and Critical Theory (the Frankfurt School), Normative Theory, and later on Poststructuralism and Constructivism (all of which have been collapsed by Robert Keohane (1988) into "reflective theory"). Robert Cox (1996[1981]:88) set the tone of the debate when he declared that

theory can serve two distinct purposes. One is a simple, direct response: to be a guide to help solve the problems posed within the terms of the particular perspective which was the point of departure. The other is more reflective upon the process of theorizing itself: to become clearly aware of the perspective which gives rise to theorizing, and its relation to other perspectives (to achieve a perspective on perspectives); and to open up the possibility of choosing a different valid perspective from which the problematic becomes one of creating an alternative world. Each of these purposes gives rise to a different kind of theory. The first purpose gives rise to problem-solving theory. [...] The second purpose leads to critical theory. (italics in original; emphasis added in bold).

By presenting themselves as offering a different, i.e., complementary type of knowledge, "critical," "reflective" IR scholars actually provided their opponents with the best institutional strategy for neutralizing their impact on the field, by democratically accepting them at most as a marginal, tolerable opposition to mainstream IR. The most successful strategic use of the criterion of purpose is revealed in Kenneth Waltz's reply to (or rather, ignorance of) Richard Ashley's criticisms. Ashley (1986:262-263) points to the "scientifically inscrutable ideological connotations" that are hidden by Neorealism's positivistic, allegedly neutral assessment of reality. By transforming science into a "purely technical enterprise," Neorealism produces "an ideology that anticipates, legitimizes, and orients a totalitarian project of global proportions: the rationalization of global politics". Waltz's response to Ashley is a textbook case of rhetorical denigration, summed up by Anna Agathangelou and L.H.M. Ling (2004:27, ft. 11) in an adequate "Hunh??": declaring his opponent to be incomprehensible, Waltz finds his way out of Ashley's "maze" in a rejection of the latter's criticism altogether as simply irrelevant. Drawing on the purpose of theory as a standard for explanation, Waltz thus considers that "critical theory," which "seeks to interpret the world historically and philosophically," is a completely different endeavor than "problem-solving theory," which "seeks to understand [the world] and explain it". More importantly, the former type of theorizing provides "no clue about how to write an improved theory of the latter sort" (Waltz 1986:341). Insofar as Waltz, like other Positivists, is interested in explaining rather than understanding world politics, the epistemic distinction that is thus set as a standard of cognitive rigor provides the framework that keeps hermetically separated the realm of facts from that of values, thereby combining the "moral non-cognitivism" of Positivist empiricism to its "instrumentalist" approach to world politics (Spegele 1996:7). As Robert Crawford (2000:150) notes, "in declaring [his] failure to understand [Ashley]," Waltz 
"appear[s] to make a conscious symbolic declaration about what can, and cannot, be said to count as a contribution to IR theory". This is such a successful disciplinary strategy that "not taking Ashley seriously has become a bit of an industry in its own right" (Crawford 2000:151).

Waltz's response reveals the practical usefulness of the consensus on purpose for immunizing theory from any accusation of, or reflexion on, ideology, and more generally from the "problem of values," however it may be defined - for, in this line of argument, it does not need to be defined at all, since it can simply be evaded. The focus on the purpose of theory as a demarcation criterion has thus served to blur - and practically annihilate - the question of values in its epistemic and ontological dimensions, and consequently, to relegate it to the margin of the field. In other words, the consensus over the idea that the question of values is problematic only if one is interested in it has contributed to postponing its treatment as a legitimate cognitive and practical problem of international theory. Since the end of the 1980s, "critical," "reflective" theory has indeed managed to coexist with mainstream IR, but merely in the form of a marginalized, self-appointed "dissident" scholarship, "speak[ing] from the margins" (Ashley and Walker 1990b:367) in "the language of exile," and claiming an "extraterritorial," "politicized non-place" from which it attempts to "think other-wise" in "a way that makes possible the testing of limitations and the exploration of excluded possibilities" (Ashley and Walker 1990a:263; emphasis in original). Mainstream IR has acknowledged its presence and tolerated its claim to usefulness, while at the same time questioning its paradigmatic and empirical potential (Keohane 1988) and the extent of its "belonging" to the field, thereby actually "excluding" it as a "possibility":

[critical IR] leads to a dead end, or perhaps more accurately, to a new road with a destination that bears little or no resemblance to international politics...along this route we learn a great deal about the innumerably contested ways of how to think about a subject matter, but almost nothing about the subject itself. (K.J. Holsti, quoted in Crawford 2000:153; emphasis in original)

By shifting the problématique of "critical theory" from an epistemic to a practical one, the focus on purpose has, then, managed to transform the demarcation between "problemsolving" and "critical" theory into a social one, separating two different communities of scholars who can coexist democratically as long as they do not attempt to question one another's validity and hence legitimacy. With this arrangement, "problem-solving" theorists can simply "outsource" the question of values to "critical theorists", with no reflexive effect on their own theoretical or empirical production. As Pierre Bourdieu (2004[2001]) notes with respect to other epistemic dichotomies in social science, the relationship between epistemic and social divisions is often veiled, and academic debates often serve to hide it even more, thereby immunizing it from the (reflexive) gaze of the socio-analyst. It is, then, not surprising that some consider Positivism to have "produc[ed] a discipline that is marked by political assumptions masquerading as technical ones" (Smith 2004:503), hiding or permitting, behind conceptual notions of purpose, ideological and political interests and implications, and behind the commitment to value-freedom, a real "value-commitment" to a scientistic notion of "progress" (Jackson 2008:138).

The institutional and social division of the field along this demarcation line is manifested in the social organization of the discipline itself. It has become a commonplace today to say that IR is both a "divided" and "dividing" discipline (Holsti 1985), with a centre of production still 
solidly rooted in the Positivist, empiricist culture of the American academy (Hoffmann 1977; Crawford and Jarvis 2001) and its "hegemonic" status within international IR (Holsti 1985; Smith 2002). The marginalization of "critical," "reflective theory" is also visible in the field's curriculum and its lack of inter-disciplinarity, in the segregation of its scholars' research interests in the different sections of the ISA and the American Political Science Association, in the editorial policies of its academic journals (Katzenstein, Keohane and Krasner 1998; Waever 1998), and its funding, recruitment, promotion and tenure policies (Smith 2002:72; Agathangelou and Ling 2004). With the social value of Science being unchanged in Western societies, IR scholars are not particularly encouraged to present themselves as anything else than "scientists," and are still marginalized and undermined if they "market" themselves otherwise (Smith 2004). The "prescription for a rigorous philosophy-avoidance strategy for the practicing social scientist" (Lapid 1989:235) has therefore shaped IR scholars' habitus in important ways, by shaping not only their practice, but also their cognitive and social dispositions as knowledgeproducers (see Bourdieu 1980).

The social-institutional division between mainstream scholars and the "dissidents" of the 1980s and 1990s seems, however, to have somewhat shifted in American IR. A recent survey that attempts to identify the lines of fracture in the field (Hamati-Ataya forthcoming 2011b) points to the institutionalization of the older generation of "dissidents" (who nonetheless still identify themselves as such), and the emergence of a new generation of scholars whose cognitive commitments are more diffusely but more antagonistically opposed to contemporary "mainstream" American IR scholarship than their predecessors' were. The older divisions are still visible, with the concentration of the great majority of American IR within the research concerns of "positivism," "rationalism," and "materialism," and the remaining part of the field constituted by a loose, heterogenous group of scholars more directly concerned with values, identity, language and knowledge as central to IR's subject-matter, and committed to a more "anti-positivist," "constitutive," "sociological" approach to world politics. The lower institutional status of this new generation of scholars, in opposition to both that of "mainstreamers" and of the now-tenured "dissidents" of the 1980s, points to the fragile situation of the new "anti-mainstream" American IR scholarship, to the marginalization of its research interests and social concerns, and therefore to the unlikelihood of seeing it significantly impact and transform current disciplinary mindset and practice.

This suggests that the discipline has now entered a new cycle of dissidence/marginalization, and it is therefore legitimate to question the extent to which "it is extremely unlikely that the study of international relations will quickly relapse into the insularity which prevailed before [post-positivism] began to be explored" (Linklater 1992:78) ${ }^{\mathrm{vi}}$. Insofar as the problem of values is intrinsic to the problématique of reflexivity, the second part of this paper proposes that a reflexive analysis of this problem in IR scholarship should also search for possible ways of avoiding the endless repetition of this disciplinary pattern, by redefining both the cognitive tenets and social practice underlying IR scholarship's attitude vis-à-vis the problem of values. 


\title{
REFRAMING THE SOLUTION: OUTLINE FOR A REFLEXIVIST RESEARCH PROGRAM AND PRACTICE
}

\author{
The epistemic tenets of Reflexivism
}

The terms of the cognitive debate between "problem-solving" and "critical theory" are grounded in the idea that the scholar's concern for the problem of values is dependent on the purpose of theory, and that "problem-solving theory" can avoid the problem altogether because it is motivated by a different cognitive and social concern. When Cox (1996[1981]:88; emphasis in original) noted that "theory is always for someone and for some purpose," he explicitly meant that no social theory was exempted from this constraint. However, his affirmation that "problemsolving" and "critical theory" have two "distinct purposes" is not sufficient to undermine Positivists' claim to neutrality and universality. Indeed, this distinction implies that "problemsolving" theory is the result of individual scholars' freedom of choice in terms of purpose, and that purpose itself can be conceptualized and pursued independently of exogenous social constraints.

Of course, any scholar is perfectly free to define her purpose as she wishes, just as any human being is free to defy the "law" of universal gravitation by jumping from a rooftop with no flying apparatus. This freedom, which is intrinsic to human behavior, does not in and of itself invalidate the "laws" of nature as we understand them. Similarly, the illusion that a scholar can simply choose to deny the social embeddedness of her cognitive process does not invalidate the factuality of such embeddedness, nor does it neutralize its impact on the processes and outcomes of theorizing. Insofar as the demarcation crystallized in the notion of purpose is intimately related to the idea that social science can produce a type of explanatory theory that is independent of the historicity of thought, and hence of the socio-historical and ideological origins and grounding of knowledge, the relevance of purpose as an analytical-turned-social demarcation criterion is de facto undermined by the findings of the sociology of knowledge. By addressing the "problem of values" itself through a sociological analysis, the first part of this paper, then, intended to empirically put to practice the post-positivist claim that cognitive claims and concepts are not independent of socio-ideological factors.

This also suggests, however, that a truly reflexive cognitive commitment cannot merely stop at a stage of deconstruction of past or contemporary cognitive claims, and should go beyond this, moving from the results of this deconstruction and taking them as the starting-point for the formulation of a significantly different mode of theorizing. In other words, reflexivity should lead to Reflexivism, as I use the terms here. Reflexivism is, then, not merely grounded in the idea that one can no longer objectivate social reality along the lines defined by the correspondence theory of truth. The shifting of the cognitive tenets of Positivism entails not only the acknowledgment of the historicity of thought in the form of "social mutability" and "historical contingency" (Lapid 1989:243), but also the redefinition of scientific validity, so that the investigation of the epistemic validity of knowledge and the investigation of its social determination (Mannheim 1936) can be finally reconciled. This requires a move beyond "critical" theory understood as a meta-discourse (Cox's "perspective on perspectives") so as to challenge Positivism on its own turf, and to redefine objectivity within a non-foundationalist epistemology. This, in turn, entails a theory of knowledge that can acknowledge and cope with the fact that knowledge is always produced out of pre-existing knowledge and that validity cannot be determined in the absolute but should be objectivated as a self-corrective, dynamic 
standard that does not follow a linear logic of cumulation and proof. This epistemic stance is important because it alters the way we conceptualize the relationship between the factual and the axiological/normative, insofar as it no longer problematizes facts/values within a foundationalist theory of correspondence and re-presentation. It consequently also challenges the idea that it is only by adhering to the fact/value dichotomy that one can preserve some form of ontological realism.

Reflexivism, therefore, goes beyond reflexivity, i.e., beyond the mere "reflexion on" the ways of knowing an object (Holsti), to the objectivation of the ways of knowing and of the object as mutually constitutive. It endeavors not merely to extract scholarship from the Positivist doctrine of representation, but also to move beyond the "twin fallacies" that have recently been framing discussions of epistemology in IR (Kratochwil 2007:2-3):

First, that in the absence of secure universally valid and trans-historically established criteria everything becomes "relative" and that, therefore, the adherents of a more critical or pragmatic orientation towards knowledge have to be either nihilists or charlatans since they deny "truth". Second, and in a way the flipside of the first fallacy, since the foundationalist claims of traditional epistemology can be shown to be faulty, indeed "anything goes" and we need not worry about criteria that warrant our knowledge claims.

This entails the development of explanatory models that can ground themselves in history as a factor that affects and shapes both the social determination of knowledge and the standards of its epistemic validity, thereby establishing some measure of pragmatic objectivity for our standards of assessment (Hamati-Ataya forthcoming 2011a). Reflexivism in this sense does not withdraw from the realm of theorizing, as if "meta-theory" were an "unproductive distraction from the 'real substance' of the discipline", but rather establishes itself as a type of meta-theory that is both "the indispensable foundation of competent scholarly activity, and vital for ensuring the adequacy of the explanatory accounts which are developed" (Neufeld 1993:54) and a form of first-order theory proper (see Pouliot 2007:379 and Hamati-Ataya 2010).

Reflexivism, thus defined, finds its common roots in different post-positivist approaches, such as Critical Theory, some forms of Constructivism, as well as Pragmatism and Critical Realism $^{\text {vii }}$. Each of these theoretical orientations has made important contributions that undermine the cognitive tenets of Positivism and establish a general outline for reflexive scholarship. And although they are often viewed as incommensurable, and divided over their ontological/epistemic commitments and the praxeological stances that result from them, they share enough in common to be more than just a loose theoretical opposition to Positivism. The project of reconstructing their common, underlying Reflexivist framework can of course not be carried out within the limits of this paper, but what follows is somewhat guided by the idea that we need to "devise new roads to commensurability" (Lapid 1989:248-9) despite the loss of "the Archimedean point of indubitable knowledge" (Neufeld 1993:58). My purpose is here restricted to showing that Reflexivism can provide us with a different understanding of the question of values in both its cognitive and social dimensions. 
Values from a Reflexivist viewpoint:

Reversing the premises of Positivism

A reconsideration of the problem of values may find some preliminary guidelines in the fact/value dichotomy itself. Given its predominance in the literature, one would expect to find a definition of values that explains or justifies the meaningfulness of the dichotomy as an ontological a priori, yet interestingly enough, no such definition is available. It is indeed much easier to give examples of values than to actually say what values are. There thus seems to be a general consensus that freedom, justice, and truth are such examples, but there is no equally consensual view of what their common nature is. In fact, as Felix Oppenheim (1973:55) remarked,

[t]o speak of "facts" and "values" is misleading - as if facts and values were things and could be divided and "allocated" like pieces of pie. The affirmation and the denial of the separation between facts and values are theories about the factual and evaluative meaning and function of concepts and statements; as such they belong to the philosophy of language. (emphasis added).

This may explain why the distinction between facts and values is often embodied in that

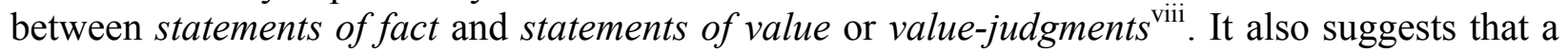
critical investigation of the dichotomy can be carried out through two different reflexive paths. The first one, as Oppenheim notes, is an investigation of social "statements" or utterances as the subject-matter of a theory of politics that is informed by a sociology of language ${ }^{\mathrm{ix}}$. The second one, which I propose to delineate here, is an investigation of the relationship between knowledge and judgment, as the subject-matter of a theory of politics that is informed by a sociology of knowledge. The relationship between knowledge and judgment, and by extension between knowledge and praxis, constitutes a fundamental epistemic concern for Reflexivism, and has been explored, more or less explicitly, by different non-positivist approaches within IR. Despite some important differences with respect to their ontological commitments, Constructivism, Critical Theory, Pragmatism and Critical Realism share to a large extent a common core that considers (1) that knowledge evolves as a self-corrective, dynamic process that does not, however, teleologically move toward a predictable end-point; (2) that knowledge and social reality are at least partially mutually reflective, and consequently that the reality of the social world is better understood in terms of meaning and interpretation (hermeneutics) than correspondence and representation; and (3) that the mutual embeddedness of facts and values forces us to acknowledge the intimate connections between knowledge-production on the one hand, and social determination and social change on the other. A brief reconstructive review of these assumptions points to the locus from which to reverse the Positivist terms of the debate over the relationship between knowledge and judgment, and hence between the factual and the axiological/normative. This locus corresponds to the tension inscribed in a different cognitive and existential problématique, namely, not the relationship between what is and what ought to $b e$, but between what is and what can be.

Constructivism's contribution to this question emanates from its critique of the Positivist understanding of "being," which corresponds to a "reification" of social reality whereby man "forget[s] his own authorship of the human world," and results in man's illusion that the social world is because, and insofar as, it is "something outside of himself" (Berger and Luckmann 
1991[1966]:106). Assuming, rather, the constitutive role of ideas and beliefs, Constructivism adds a question that has become irrelevant for Positivism": "How is it possible that subjective meanings become objective facticities?" (1991[1966]:30). Although most theoretical and empirical Constructivist contributions in IR have explored this "becoming" with respect to the subjects of social action that are observed by the knowledge-producer (Hopf 1998:184), it has recently been expanded more explicitly to the observer herself, notably in the work of Stefano Guzzini. Stressing on the need to "take seriously" both "the interpretivist and the sociological turns in the social sciences," Guzzini suggests that a constructivist knowledge of the social world must, on the one hand, "analyse [the] relationship" between "the level of common-sense action" and the level of "second-order action (or, observation)" (Guzzini 2000:149), and on the other, "problematize" the "relationship between the social world and the social construction of meaning (including knowledge)". Moreover, "the relationship between observation and action proper needs to be problematized in a 'reflexive' way" (Guzzini 2000:150). Such a "reflexivity" places the "questions about the relation between meaning/knowledge and power" at the heart of the constructivist project, thereby suggesting that "the central issue of power [...] is [...] not so much a question of research taste" as it is one of "theoretical logic" (Guzzini 2000:150). This entails, then, a "critical Constructivism" (Hopf 1998) that is more specifically concerned with problematizing the relationship between science and politics (and between their respective shared values/knowledge) as a doubly reflective manifestation of the relationship between the social construction of meaning/knowledge of researchers as/and social actors, and the construction of social reality by researchers as/and social actors.

In a similar fashion, Critical Theory stresses on the dialectical relationship between knowledge and praxis, or between thought and history. The question of values is inscribed in the relationship of ideology and social interests to the production of knowledge. From a Critical perspective, at least some groups' interests and values manifest themselves in the production of allegedly universal visions of the world (and, as Bourdieu would say, simultaneously of its divisions). The production of a knowledge of world politics is therefore necessarily grounded in material global structures of power, and the (di)visions of the world that are thereby re-presented can therefore not be granted the kind of "neutrality" that Positivism posits and aspires to. As the realm of knowledge becomes merged with the realm of politics, the fact/value dichotomy that serves to isolate cognitive claims from evaluative or ideological ones becomes itself a feature of (bourgeois) ideology (Marcuse 2002[1964], Chap. 6). Against the Positivist static view of both knowledge and reality, Critical knowledge is hereby viewed as a spiral-like socio-intellectual process that is constantly "confront[ing] all its statements on the subjective experience, conscious and unconscious, of human beings and human groups, with the objective factors determining their existence" (Adorno 1976[1957]:250) - and therefore its own as well. As the process actualizes itself by exploring and bringing into existence the "historical alternatives" to existing modes of material-cognitive domination, "the values attached to the alternatives do become facts when they are translated into reality by historical practice" (Marcuse 2002[1964]:xlii, emphasis added).

As "an approach to knowledge that takes its departure from acting rather than from reason itself, or from 'being' or speculations" (Kratochwil 2007:14, ft.), Pragmatism also acknowledges the positive connection between knowledge and judgment/praxis, and therefore problematizes both knowing and the known in relation to the practical context of interaction wherein reality gains meaning for the observer. Since the "process of knowledge production" is a "social practice determined by rules in which scientists are not only constitutive for the 
definitions of problems" but also constantly re-assess and "debate questions that seem "undecidable"" (Kratochwil 2007:12), the process of knowing is inscribed in an open temporality that acknowledges both the historicity of thought and the historicity of judgment. The grounding of knowledge/judgment in a reality that exists through the practical significance that it acquires for subjects placed in an evolving context of observation/action therefore also allows for a problematization of the relationship between science and politics, based on the "insight - on the wager - that the temporary isolation of a given value-commitment from the ordinary flow of daily life might be the best chance of refining that value-commitment to allow it, and the actors who stand by it, to face the open-ended future" (Jackson 2009:659). This implies that as knowledge is produced out of evolving and ever-renewed constructions of pragmatic meaning, the assessment of what is, can be, or ought to be is altered as contextual knowledge/praxis evolves (Hamati-Ataya forthcoming, 2011a).

The same view of knowledge as a self-corrective, dynamic process characterizes Critical Realism, which acknowledges that knowledge of reality "must come about through a transformation of pre-existing knowledge," and that science proceeds "through a constant spiral of discovery and understanding, further discovery, and revision, and hopefully more adequate, understanding," without assuming "that the scientific endeavor could ever come to an end" (Patomäki and Wight 2000:224). Critical Realism, however, defines itself as a theory of reality rather than a theory of knowledge, and it is in its commitment to ontological realism that lies its potential for redefining the relationship between what is and what can be. Departing from "postpositivism," which "treats facts as nothing other than disguised values," Critical Realism acknowledges that "reality is differentiated yet interconnected. So, although facts are not merely values and vice versa, they are mutually implicating," which entails for Critical Realism to "situat[e] a genuinely critical moment at the heart of analysis; a moment that depends at once upon values being factually explained and facts being subject to evaluation." (Patomäki and Wight 2000:234). This ontological principle feeds back into Critical Realism's anti-positivist epistemology, because of the "value" of "truth" itself as a defining standard for knowledge: "[f]acts are always value-laden because at the transitive dimension of science truth is a positive value and truth as correspondence to the world is a regulative metaphor guiding scientific and other practices" (2000:234; emphasis in original).

The partial reconstruction of the main tenets of these four approaches to knowledge and reality points to three meaningful consequences for the question of values. The first is that the very relevance of the distinction between the classical categories of epistemology and ontology should be reconsidered, insofar as the ways wherein we view the reality and nature of the social world are not independent of the ways wherein we validate our knowledge of them, and vice versa. In other words, the epistemological claim that knowledge and reality are mutually constitutive is equivalent to the ontological claim that knowledge and reality are mutually reflective. This reflects the "looping effect" that is grasped by a reflexive understanding of the relationship between knowledge of the world and action in the world, where "knowledge" and "action" refer not merely to the subjects that are objectivated by the researcher, but to the researcher as a subject as well. The corollary of the collapse of epistemology and ontology is therefore the collapse of the subject/object distinction that has provided Positivism with its central cognitive and ethical argument.

The second consequence is that, insofar as the separation of subject and object can no longer be upheld or even viewed as analytically harmless, the relationship between what is (as the alleged realm of the object(ive)) and what ought to be (the subject(ive)) should be 
reconsidered from a new perspective. In the classical terms of the debate, the normative, what ought to be, or "ultimate ends" are addressed as static, unchanging principles. However, the acknowledgment of the fact that knowledge is itself historical and governed by complex processes of correction and redefinitions (concerning its content as well as its standards of validity) should also lead to the acknowledgment that the relationship between what is and what ought to be (especially their alleged disjunction) can never be constant and set once and for all. If our knowledge of the world and of ourselves in it as thinking and acting subjects necessarily evolves through our interaction with the world, it should follow that our evaluations of how things are, can or should be also evolve in relation to this knowledge, and in relation to our everrenewed beliefs and purposes. By stressing on the historical relation between what is and what can be, which is grounded in an open temporality that instantly connects the present (as a past potentiality) to the potentialities that it can generate, Reflexivism acknowledges that norms are constantly conceptualized and assessed in relation to past and present knowledge/context/praxis, with also an awareness of what these same norms might mean for us in light of future knowledge/context/praxis. This suggests that the question of whether norms can be deduced from facts is the wrong question, and that the relationship between "ideals" and "reals" is itself inscribed in the historicity of thought and action, and therefore can, and should be investigated in a recursive, reflexive manner.

Such a reflexive approach to norms also transforms the meaning of what Positivism views as problematic, namely, that it is not possible to validate norms in the absolute or against one another. From a Reflexivist perspective, norms cannot be conceptualized independently of the socio-historical context wherein they are both formulated and assessed. If one thinks in these terms, the fact/value dichotomy loses its relevance as an ontological a priori, because both items of the dichotomy are now subjected to a similar standard of assessment. And just as we cannot know today what we will know tomorrow, we similarly understand that we cannot assess which values will be preferred in the future. We acknowledge, nonetheless, that the valuable can be defined, evaluated and acted upon in relation to a knowledge that is itself self-corrective and pursued indefinitely.

Finally and consequently, the Reflexivist perspective also forces us to reconsider how the relationship between value-freedom as a deontological norm (a manifestation of what ought to be) and the fact/value dichotomy as an ontological given (what is) has hitherto been posited by Positivism, namely, that the fact/value dichotomy produces the requirement of value-freedom. As shown previously, the rationale of this causal logic can be challenged, in the sense that it is legitimate to ask whether the practice of value-freedom (and by extension, moral neutrality) is rationally deduced from the cognitive assessment of the validity of the fact/value dichotomy, or whether it is in fact the socially grounded praxis of value-freedom that has given cognitive relevance and meaning to the fact/value dichotomy as a universal ontological a priori. Insofar as Reflexivism acknowledges the mutual constitutiveness of meaning/knowledge and praxis, the answer to the question is "both," and the "how" and "why" of this relationship become more pertinent than the "what". The next stage in reversing the culture of Positivism should therefore be concerned with revisiting the notion of value-freedom as an ethos for scholarly practice. 


\section{Reflexivism and the social practice of scholarship: Toward a post-Weberian ethos}

A "sociology of reflexivity" in IR, if undertaken, might identify the concern for "emancipation" as one of the loci for the emergence of reflexivity as a mode of conceptualizing knowledge and its social role. This explains why reflexivity is often viewed as being included in, or inclusive of, an emancipatory project for IR scholarship (Hoffman 1987; Neufeld 1993 and 1995; Linklater 2007). Given that emancipation can be conceptualized in terms of values (at least because it is itself defined as something "valuable"), emancipatory reflexive theory necessarily challenges the notion that knowledge is divorced from judgment and that scholarship is agnostic with respect to political and moral purpose; and it is in its own grounding in values that it commits itself to reflexivity as an epistemic necessity (see Horkheimer 1976[1937] and Marcuse 2002[1964]:xli). Reflexivity can, however, be conceptualized within a sociological approach without necessarily being grounded in a pre-defined conception of emancipation, thereby allowing the self-corrective nature of knowledge to alter our understanding of the valuable rather than imprisoning it in predetermined and rigid normative paths that may become oblivious to their own historicity. The purpose of a specifically sociological approach to reflexivity is to reveal the ways wherein "the academic studying truth and power is not someone free from the effects of power" (Smith 2002:70), by approaching power "in a way which allow[s] [...] to view socially constructed knowledge as a constitutive factor of social power and which, relatedly, make[s] it possible to conceive of the relationship between power and [cognitive] consensus" (Guzzini 2000:172).

This relationship has been made "invisible" by Positivism's commitment to the correspondence theory of truth understood as a corollary, and a guarantee, of objectivity and its corresponding "view from nowhere". As Smith (2002:83) puts it,

[p]recisely by portraying the discipline as having a core that reflects the world "out there," and precisely by deeming some methods as appropriate (and others as inappropriate) to studying that world, international relations, US-style, engages in the politics of forgetting its own role in the practices of international relations.

Positivism's deontology is, then, similar to, and derives from, its epistemology: just as Positivism preserves - and thereby reproduces - the reification of social reality by perpetuating the "forgetfulness" of its man-made construction, so does it preserve - and thereby reinforces - the reification of the valuable by perpetuating the "forgetfulness" of the role of knowledge/praxis in reproducing or altering social reality and its underlying normative order. One of the greatest paradoxes of the culture of Positivism, then, is that it has made widely acceptable and possible a collusion with power while at the same time claiming that scholarship should refrain from producing any value-laden judgment on power. The separation of politics/ethics from the realm of science has therefore established a practice of moral and social irresponsibility, in the sense of non-accountability. The view is that since science is only tangentially or circumstantially concerned with values, judgments or norms, it does not fundamentally become polluted, involved, or responsible through intercourse with them.

Some IR scholars have questioned this Positivist ethos, asserting that "claims of neutrality smoke-screen alignments with power structurally, institutionally, and personally" (Agathangelou and Ling 2004:36), and therefore that we 
need to reflect on the possibility that both the ways in which we have constructed theories about world politics, and the content of those theories, have supported specific social forces and have essentially, if quietly, unquestioningly, and innocently, taken sides on major ethical and political questions. (Smith 2004:500; emphasis added)

IR scholarship is therefore more sensitive today to the idea that a reflexive IR must necessarily include an investigation of knowledge itself. As Bourdieu has forcefully put it, "the theory of knowledge is a dimension of political theory because the specifically symbolic power to impose the principles of the construction of reality... is a major dimension of political power" (quoted in Guzzini 2005:520). Consequently, "[m]eta-theories do matter both empirically and politically" (Guzzini 2000:156), and ideology need no longer be avoided as a polluting or incriminating factor, but should rather be embraced and problematized as intrinsic to the processes (and meaning) of knowing (Cox 1996[1985]:56-7).

Reflexivism also objectivates reflexivity itself as the product of given socio-historical contexts, "September 11" arguably being the latest significant one for IR. Within our contemporary setting, Democratic-Peace theorists - who, not accidentally, are themselves proponents of value-freedom (Steele 2007:39) - have provided a concrete empirical case study for recent reflexive IR scholarship, because the Democratic-Peace thesis was explicitly used by the Bush Administration to justify its post-September 11 policies in Iraq and Afghanistan. This has led to discussions of "the scholarly responsibility ensuing a theoretical imperative," which can be viewed as analogous, in the realm of the academy, to the "political responsibility ensuing a democratic imperative" (Ish-Shalom 2008:680). Piki Ish-Shalom (2008:688) thus points to the difference between the properly "moral responsibility" of theorists and their "social responsibility". "Social responsibility" is the "responsibility ascribed to someone well placed to identify and remedy a social problem," which in this case relates to the processes of "politicization" and "trivialization" that operate when a theory travels from the realm of the academy, where it is legitimate only insofar as it can be subjected to specific standards of validity and use, to the realm of politics, where it becomes shaped by the interests and performative rhetoric of social agents. While such processes cannot be imputed to theorists unless they actually participate in them, scholars can nonetheless not remain oblivious to them or to their effects. "Thus, even if theoreticians are not to blame for the Iraq War, they are certainly the people most capable of reflecting upon their theory's politicization and trivialization" (IshShalom 2008:688 ${ }^{\mathrm{xi}}$.

This suggests that IR scholars are invited not merely to "reflect upon" the social and moral dimension of their work, but to also make this reflexion a socially useful one, by espousing an ethos of social engagement. Wesley Widmaier (2004:443) demonstrates that such an "engaged IR" should "involv[e] an ongoing involvement in both scholarly and public debates," which the younger generation of "dissidents" in IR seems less willing to engage in than their predecessors (Hamati-Ataya forthcoming 2011b). While this retreat from the public sphere is at least partly the result of the general culture of disengagement that characterizes the discipline, the absence of some clear roadmap for IR scholars to identify the standards and rationale of an engaged ethos is equally to blame. Insofar as "critical," "normative" and "reflexive" IR has expressed its dissatisfaction with the current state of the discipline, its scholars are expected to provide the field with alternatives to the Positivist ethos of neutrality. Reflexivism, therefore, should make this attempt as well. 
As suggested earlier in this paper, the treatment of the question of values requires some measure of consistency between epistemic/ontological and axiological/normative propositions. A Reflexivist deontology should therefore be grounded in a Reflexivist epistemology/ontology. On the one hand, Reflexivism acknowledges the historicity of thought/knowledge/theory and therefore contextualizes IR scholarship - understood as a field of social production - within the general social structures wherein it is inscribed, with a special concern for those that involve "power," however it may be defined. On the other hand, Reflexivism reconciles the realms of knowledge, judgment, and praxis, by subjecting them to a unified measure of meaning/validity, and by inscribing them in an open temporality that considers these manifestations of human behavior as historical potentialities whose meaning/value evolve through time, depending on both context and purpose. Consequently, the acknowledgment of the historicity of knowledge and thought from a Reflexivist perspective necessarily entails the acknowledgment of the historicity of action/praxis as well. Taking the "interpretivist and sociological turns," then, means firstly that the problématique of reflexivity should be inscribed not only in a metatheoretical endeavor, but also in a social one that is informed by our knowledge of the social processes wherein scholarship is inscribed; and secondly, that these two endeavors - metatheoretical and social - should be mutually supportive, since they are, according to Reflexivism, mutually constitutive. The Reflexivist ethos, therefore, actualizes itself through two interdependent tracks.

The first track concerns Reflexivism as a field of cognitive production, that is, both the production of Reflexivist knowledge and the social organization of such a production. Contemporary IR responds to a more or less Positivist approach to knowledge, thought, theory and science, wherein disciplines are organized in a way that reproduces the epistemic and ontological premises and research agendas of Positivist scholarship, including its definition of its subject-matter. Insofar as Reflexivism views IR itself (and knowledge in general) as an integral part of the political, a Reflexivist IR curriculum/research program should reflect such a view, by including the sociology/history of knowledge as an integral part of IR's subject-matter. Many scholars today are dissatisfied with the rigid institutional and intellectual categories that govern their positioning within academia as well as the standards and labels imposed on their scholarly research and identity. The recent promotion of inter- or cross-disciplinarity within IR is from this perspective not so much a progressive indicator of academic and intellectual development, as it is a palliative for the breakdown of the social sciences into isolated social fields of production that have lost the memory of their relatedness. From a Reflexivist viewpoint, just as IR metatheory is pursued as a form of IR theory proper, IR scholarship that engages the sociology of the field (and other social sciences) is not inter-disciplinary as much as it is, properly speaking, intra-disciplinary.

Within this different curricular and intellectual setting, Reflexivism enjoins us to empirically investigate the mutual reflectivity of knowledge and reality, and to produce a type of knowledge that is not oblivious to it. In other words, Reflexivism does not aspire to produce an eternal or universal discourse on reality, but rather a knowledge that responds to its own historicity, embraces the contextuality of its research problems, and dedicates itself to producing historical meaning rather than transcendental truths. In the current historical/institutional context IR finds itself in, the choice to investigate the field of knowledge is itself a historical choice, which responds to the situation (cognitive, political, and moral) that reflexive IR scholars currently question or reject. This provides the link to the second track, which is concerned with the properly social/moral dimension of Reflexivist scholarship. 
Insofar as the Reflexivist perspective acknowledges the historicity of both knowledge and judgment/praxis, the Reflexivist ethos cannot produce an essentialist deontology that associates scholarship (or science in general) to a specific social or moral value - especially truth, whose definition is precisely an object/stake of politics. In other words, the inscription of scholarly judgment/praxis in its historical context, and the reflexive awareness that this historicity cannot be transcended, preclude the reference to an ideal-type of scholar of the kind Weber envisaged, or to any sort of typology for the practicing scholar, whether she restricts her social role to the institutional realm of the academy, or decides to engage the wider public sphere. As Reflexivist scholarship investigates the relationship between the production of knowledge and the production of social order and norms, it provides itself with the means to both better understand and better shape its own social praxis. The construction of ideal-typical categories for defining such a praxis would be pointless and non-productive, insofar as action can only gain meaning within the particular context wherein it is inscribed and which affects its potential outcomes. "Dissident" scholarship, in this sense, will be different - and therefore be subjected to different standards and requirements - in different socio-political contexts. These need to be identified empirically and addressed accordingly.

The acknowledgment of the plurality of social settings for the practice of scholarship also raises important issues and dilemmas that the discipline cannot remain oblivious to. Western scholarship assumes the existence of benign social structures that promote or allow the practice of a Weberian or Sartrean social engagement - freedom of expression, access to the public, protection from physical harm, right to oppose, etc. - that thousands of scholars around the world do not enjoy, and for whom acts of resistance may translate into more violent - and, from a Western perspective, less "politically correct" or "civilized" - practices. As Alain Badiou (2005[1998]) rightly notes, contemporary Western societies themselves have erased from their collective memory the violence of their own intellectuals against local or foreign oppressors. At another, perhaps more important, level for the discipline as a whole, non-Western scholars who engage in a reflexive assessment of IR may become skeptical as to the usefulness of the discipline. Insofar as they find themselves, their identities, societies, and perceived interests to suffer from the effects of the knowledge-power nexus that reflexive IR is so keen on investigating and altering, they may wonder whether any "subaltern" knowledge is worth producing at all, if there is no possibility for them to significantly transform the material and ideational realities that maintain and reproduce their subjection to Western hegemony including Western cognitive violence. While physical violence may seem to be an extreme act of intellectual/political resistance, the refusal to produce a knowledge that may serve to oppress one's people, culture, and future development may just be an equally rational option. Given the contemporary hegemonic status of Western (American) IR, reflexive IR scholars who find themselves on the higher end of the knowledge-power nexus should be willing to engage these issues if they are truly "interested in producing knowledge sensitive to multiple global realities" (Tickner and Tsygankov 2008:661), as the 2007 ISA Meeting organizers suggested.

The "sociological" turn that is implied in the practice of reflexivity therefore entails an understanding of the historicity of the scholarly ethos itself. Informed as it is by an empirical study of knowledge as a social field of production, Reflexivism does not merely reject the Positivist "view from nowhere". It rejects, more importantly, the idea that as a social group, scholars are both equidistant (in terms of embeddedness and interest) from all other social groups and that they themselves constitute some sort of uniformly interested community. There is, indeed, no empirical support for the idea that scholarship can be defined by some unique, $a$ 
priori value or some standard praxeology, and the Weberian ideal-typical approach to scholarly deontology, as well as the model of the "public intellectual" à la française, have perhaps served to perpetuate this illusion. Weber's purpose was to define for the academy a place from which it could speak critically and independently to power, and for society. Society itself, however, cannot be treated as a monolithic entity, or analytically opposed to government and power. And neither can science. IR scholars therefore find themselves inscribed in the very processes they describe, and their social praxis/ethos should be defined according to this specific locus, which unavoidably positions them, and their knowledge, against one another, and against other social groups that need to be identified in every given social setting. This particular dilemma therefore needs to be investigated and addressed realistically, and Reflexivism offers us the means to do so, without imposing the terms or ultimate objectives of scholarly practice.

Our time and context, then, call for a different ethos than the Weberian one, in light of the development of our knowledge, of the world, and of the political dimension of science since Weber last contemplated them. If we accept the historicity of our thought and the historicity of our praxis as parameters for our scholarship, we should then also reject cognitive and praxeological standards of universality and accept to produce a type of knowledge that will not go down in history as an eternal truth, but as a historical manifestation of meaningful, responsible social action. Such a politicized understanding of scholarship is intrinsic to IR's reflexive - and Reflexivist - project. It may converge with the emancipatory aspirations of some post-positivist schools of thought, but it cannot commit itself to a given understanding of emancipation - or politics - especially one that does not question its own origins and historicity. Just as Positivism has provided a general cognitive framework for the production of various theories, paradigms, and research programs that compete for cognitive and praxeological meaning, so does Reflexivism provide us with a general cognitive framework for the production of a plurality of approaches that investigate the mutual reflectivity of knowledge and reality, and that pursue a reflexive social practice. Reflexive scholars are therefore invited to promote socioinstitutional settings, research programs, and social interventions that will allow Reflexivism to flourish and explore the many cognitive, social and ethical alternatives that are available for the pursuance of a cognitively and socially more relevant and responsible scholarship.

\section{CONCLUSION}

This paper finds its origins in a commitment to reflexive scholarship, and simultaneously in the intuition that the problématique of reflexivity itself originates in an implicit collective awareness that something is wrong with the way Western scholarship has hitherto defined its position with respect to values. There was, therefore, no better way for engaging (in) reflexivity than by looking at the "problem of values" in IR. This "problem," as I hope to have established here, exists as such only for Positivism. Reflexivism, rather, calls for a reframing of the question of values as merely an intrinsic dimension of the "problem of knowledge," which needs to be reflexively embraced as a particular, albeit central, object of political theory.

By showing how specific exogenous factors played an important role in shifting the cognitive assessment of the question of values as well as IR scholars' habitus, this paper not only demonstrates the need to reflexively conceptualize and investigate the mutual reflectivity of knowledge and reality, but also argues that we can alter our knowledge and social practice in light of such a reflexive understanding, thereby inscribing our ethos in a self-corrective framework that can cope with the real processes that subtend our scholarship. Reflexivism, 
therefore, has two important things to offer IR: the inscription of its knowledge-claims in a reflexively conscious understanding of how we are produced as knowing and acting social subjects, and the inscription of its social practice in an intellectually honest, morally empowering, and responsible understanding of the present and the future.

\section{WORKS CITED}

Acharya, Amitav. (2004) Whose Norms Matter? Norm Localization and Institutional Change in Asian Regionalism. International Organization, 58(2):239-275.

Ackerly, Brooke and Jacqui True. (2008) Reflexivity in Practice: Power and Ethics in Feminist Research on International Relations. International Studies Review 10(4):693-707.

Adorno, Theodor W. (1976[1957]) "Sociology and Empirical Research." In Critical Sociology: Selected Readings, edited by Paul Connerton, pp. 237-257. Harmondsworth, Middlesex, England: Penguin Books.

Agathangelou, Anna M. and L.H.M. Ling. (2004) The House of IR: From Family Power Politics to the Poisies of Worldism. International Studies Review 6(4):21-49.

Art, Robert J. et al. (2002) War with Iraq is not in America's National Interest. New York Times September 22.

Ashley, Richard. (1986) "The Poverty of Neorealism." In Neorealism and its Critics, edited by Robert O. Keohane, pp. 255-300. New York: Columbia University Press.

Ashley Richard K. and R.B.J. Walker. (1990a) Introduction: Speaking the Language of Exile: Dissident Thought in International Studies. International Studies Quarterly, 34(3):259268.

(1990b) Conclusion: Reading Dissidence/Writing the Discipline: Crisis and the Question of Sovereignty in International Relations. International Studies Quarterly, 34(3):367-416.

Badiou, Alain. (2005[1998]) Metapolitics. London: Verso.

Barnett, Michael. (2009) Evolution Without Progress? Humanitarianism in a World of Hurt. International Organization, 63(4):621-663.

Barnett, Michael and Raymond Duvall. (2005) Power in International Politics. International Organization, 59(1):39-75.

Berger, Peter and Thomas Luckmann. (1991[1966]) The Social Construction of Reality: A Treatise in the Sociology of Knowledge. London: Penguin Books.

Bourdieu, Pierre. (1980) Le sens pratique [The Logic of Practice]. Paris: Seuil. (1984) Homo Academicus. Paris: Les Editions de Minuit. (1998[1992]) Les règles de l'art: Genèse et structure du champ littéraire [The Rules of Art: Genesis and Structure of the Literary Field]. Paris: Seuil.

(2004[2001]) Science of Science and Reflexivity. Chicago: University of Chicago Press.

Bourdieu, Pierre, Jean-Claude Chamboredon and Jean-Claude Passeron. (1983[1968]) Le métier de sociologue: Préalables épistémologiques [The Craft of Sociology: Epistemological Preliminaries], $4^{\text {th }}$ ed. Paris: Mouton.

Brecht, Arnold. (1959) Political Theory: The Foundations of Twentieth Century Political Thought. Princeton: Princeton University Press.

Brown, Chris. (2005[2001]) Understanding International Relations, $3^{\text {rd }}$ ed. London: Palgrave Macmillan. 
Bull, Hedley. (1972[1966]) "International Theory: the Case for a Classical Approach." In Contending Approaches to International Politics, edited by Klaus Knorr and James Rosenau, pp. 20-38, $2^{\text {nd }}$ ed. Princeton: Princeton University Press.

Cochrane, Molly. (1999) Normative Theory in International Relations: A Pragmatic Approach. Cambridge: Cambridge University Press.

Comte, Auguste. (1880) The Positive Philosophy of Auguste Comte. Translated by Harriet Martineau. New York: Peter Eckler.

Cox, Robert. (1996[1981]) "Social Forces, States, and World Orders." In Approaches to World Order edited by Robert Cox and Timothy Sinclair, pp. 85-123. Cambridge: Cambridge University Press.

(1996[1985]) "Realism, Positivism, and Historicism." In Approaches to World Order, edited by Robert Cox and Timothy Sinclair, pp. 49-59. Cambridge: Cambridge University Press.

Crawford, Robert M.A. (2000) Idealism and Realism in International Relations: Beyond the Discipline. London: Routledge.

Crawford, Robert M.A. and Darryl S.L. Jarvis. (eds.) (2001) International Relations - Still an American Social Science? Albany, NY: State University of New York Press.

Desch, Michael C. (2007/08) America's Liberal Illiberalism: The Ideological Origins of Overreaction in U.S. Foreign Policy. International Security, 32(3):7-43.

Dunne, Timothy. (1998) Inventing International Society: A History of the English School. Basingstoke: Macmillan Press.

Durkheim, Emile. (1953[1911]) "Value Judgments and Judgments of Reality." In Sociology and Philosophy, pp. 80-97. London: Cohen and West Ltd. (1966[1895]) The Rules of Sociological Method. $8^{\text {th }}$ ed. New York: The Free Press.

Easton, David. (1953) The Political System: An Inquiry into the State of Political Science. New York: Alfred A. Knopf (1969) The New Revolution in Political Science (Presidential Address to the American Political Science Association). American Political Science Review 63:1051-1061.

Eulau, Heinz. (ed.) (1969) Behavioralism in Political Science. New York: Atherton Press.

Fierke, Karen M. (2002) Links across the Abyss: Language and Logic in International Relations. International Studies Quarterly 46(3):331-354.

Frost, Mervyn. (1986) Towards a Normative Theory of International Relations: A Critical Analysis of the Philosophical and Methodological Assumptions in the Discipline with Proposals Towards a Substantive Normative Theory. Cambridge: Cambridge University Press.

Glaser Rafshoon, Ellen. (2001) A Realist's Moral Opposition to War: Hans J. Morgenthau and Vietnam. Peace and Change 26(1):55-77.

Greene, Thomas H. (1970) Values and the Methodology of Political Science. Canadian Journal of Political Science 3(2):275-298.

Guillaume, Xavier. (2002) Reflexivity and Subjectivity: A Dialogical Perspective for and on International Relations Theory. Forum: Qualitative Research 3(3).

Gunnell, John G. (1993) The Descent of Political Theory: The Genealogy of an American Vocation. Chicago: University of Chicago Press (2006) Dislocated Rhetoric: The Anomaly of Political Theory. The Journal of Politics 68(4):771-782. 
Guzzini, Stefano. (2000) A Reconstruction of Constructivism in International Relations. European Journal of International Relations 6(2):147-182. (2002[1998]) Realism in International Relations and International Political Economy: The Continuing Story of a Death Foretold. London: Routledge. (2005) The Concept of Power: A Constructivist Analysis. Millennium: Journal of International Studies 33(3):495-521.

Hamati-Ataya, Inanna. (2006) Connaître et Juger en Théorie des Relations Internationales: Etude du Discours Axiologique de Trois "Réalismes" en Rapport avec leurs Postulats Epistémologiques [Knowing and Judging in International Relations Theory: A Study of the Axiological Discourse of Three "Realisms" in Relation to their Epistemic Postulates]. PhD diss., University of Paris 1 Panthéon-Sorbonne, Paris, France.

(2010) Knowing and Judging in International Relations Theory: Realism and the Reflexive Challenge. Review of International Studies, 36(4):

(Forthcoming 2011a) Beyond Post/Positivism: The Missed Promises of Systemic Pragmatism. International Studies Quarterly.

(Forthcoming 2011b) Contemporary "Dissidence" in American International Relations:

The New Structure of Anti-Mainstream Scholarship? International Studies Perspectives.

Hare, R.M. (2003[1952]) The Language of Morals. Oxford: Oxford University Press.

Hobbes, Thomas. (1994[1651]) Leviathan. Indianapolis: Hackett.

Hoffman, Mark. (1987) Critical Theory and the Inter-Paradigm Debate. Millennium: Journal of International Studies 16(2):231-249.

Hoffmann, Stanley. (1960) Contemporary Theory in International Relations. Englewood Cliffs, NJ: Prentice Hall

(1977) An American Social Science: International Relations. Daedalus 106(3):41-60.

Holsti, K.J. (1985) The Dividing Discipline: Hegemony and Diversity in International Theory. Boston: Unwin Hyman.

Hopf, Ted. (1998) The Promise of Constructivism in International Relations Theory. International Security 23(1):171-200.

Horkheimer, Max. (1976[1937]) "Traditional and Critical Theory." In Critical Sociology: Selected Readings edited by Paul Connerton, pp. 206-224. Harmondsworth, Middlesex, England: Penguin Books.

Hume, David. (2003 [1739-40]) A Treatise of Human Nature. Mineola, NY: Dover (1983[1751]) An Inquiry Concerning the Principles of Morals. London: Hackett.

Ish-Shalom, Piki. (2008) Theorization, Harm, and the Democratic Imperative: Lessons from the Politicization of the Democratic-Peace Thesis. International Studies Review 10(4):680692.

Jackson, Patrick Thaddeus. (2008) Foregrounding Ontology: Dualism, Monism, and IR Theory. Review of International Studies 34:129-153.

(2009) Situating Creativity, or, the Cash Value of a Pragmatist Wager for IR. International Studies Review 11:656-659.

Jackson, Robert and Georg Sørensen. (2003[1999]) Introduction to International Relations: Theories and Approaches. Oxford: Oxford University Press.

Jentleson, Bruce W. (2002) The Need for Praxis: Bringing Policy Relevance Back In. International Security, 26(4):169-183.

Katzenstein, Peter J., Robert O. Keohane and Stephen D. Krasner. (1998) International Organization and the Study of World Politics. International Organization 52(4):645-685. 
Katzenstein, Peter J, and Nobuo Okawara. (2001/02) Japan, Asian-Pacific Security, and the Case for Analytical Eclecticism. International Security, 26(3):153-185.

Keohane, Robert O. (1988) International Institutions: Two Approaches (Presidential Address to the International Studies Association). International Studies Quarterly 32(4):379-396.

Knorr, Klaus and James Rosenau. (eds.) (1972[1969]) Contending Approaches to International Politics, $2^{\text {nd }}$ ed. Princeton, NJ: Princeton University Press.

Kratochwil, Friedrich. (2007) Of False Promises and Good Bets: A Plea for a Pragmatic Approach to Theory Building (The Tartu Lecture). Journal of International Relations and Development 10:1-15.

Lapid, Yosef. (1989) The Third Debate: On the Prospects of International Theory in a PostPositivist Era. International Studies Quarterly 33(3):235-254.

Linklater, Andrew. (1992) The Question of the Next Stage in International Relations Theory: A Critical-Theoretical Point of View. Millennium: Journal of International Studies 21(1):77-98.

(2007) Towards a Sociology of Global Morals with an "Emancipatory Intent". Review of International Studies 33:135-150.

Lynch, Cecelia. (2008) Reflexivity in Research on Civil Society: Constructivist Perspectives. International Studies Review 10(4):708-721.

Mackie, J. L. (1977) Ethics: Inventing Right and Wrong. Middlesex, England: Penguin Books.

Maliniak, Daniel et al. (2006) The View from the Ivory Tower: TRIP Survey of International Relations Faculty in the United States and Canada. $<$ http://web.wm.edu/irtheoryandpractice/trip/surveyreport06-07.pdf?\&svr=www $>\quad 2010$, March 1.

Mannheim, Karl. (1936) Ideology and Utopia: An Introduction to the Sociology of Knowledge. New York: Harvest Book.

Marcuse, Herbert. (2002[1964]) One-Dimensional Man: Studies in the Ideology of Advanced Industrial Society. London and New York: Routledge.

Marx, Karl and Friedrich Engels. (1978[1845]) “The German Ideology." In The Marx-Engels Reader, $2^{\text {nd }}$ ed., edited by Robert C. Tucker, pp. 148-200. London: W. W. Norton.

McCoy, Charles A. and John Playford. (eds) (1967) Apolitical Politics: A Critique of Behavioralism. New York: Thomas Y. Crowell.

Morgenthau, Hans J. (1946) Scientific Man Versus Power Politics. Chicago: University of Chicago Press.

(1958) Dilemmas of Politics. Chicago: University of Chicago Press.

(1965) We Are Deluding Ourselves in Vietnam. New York Times Magazine, April 18.

(1970) Truth and Power. New York: Praeger Publishers.

Nagel, Ernest. (1979[1961]) The Structure of Science: Problems in the Logic of Scientific Explanation. Indianapolis and Cambridge: Hackett.

Neufeld, Mark. (1993) Reflexivity and International Relations Theory. Millennium: Journal of International Studies 22(1):53-76. (1995) The Restructuring of International Relations Theory. Cambridge: Cambridge University Press.

Nicolaus, Martin. (1968) Fat-Cat Sociology: Remarks at the American Sociological Association Convention, August 1968. <www.colorado.edu/Sociology/gimenez/fatcat.html $>2010$, June 21. 
(1969) The Professional Organization of Sociology: A View from Below. The Antioch Review, 29(3):375-387.

Oppenheim, Felix E. (1973) "Facts" and "Values" in Politics: Are they Separable? Political Theory 1(1):54-68.

Oren, Ido. (2002) Our Enemies and Us: America's Rivalries and the Making of Political Science. Ithaca and London: Cornell University Press.

(2004) The Enduring Relationship between the American (National Security) State and the State of the Discipline. PS: Political Science and Politics, 37(1):51-55.

Patomäki, Heikki and Colin Wight. (2000) After Postpositivism? The Promises of Critical Realism. International Studies Quarterly 44(2) 213-237.

Pouliot, Vincent. (2007) "Sobjectivism": Toward a Constructivist Methodology. International Studies Quarterly 51:359-384.

Ruhs, Martin and Ha-Joon Chang. (2004) The Ethics of Labor Immigration Policy. International Organization, 58(1):69-102.

Searing, Donald D. (1970) Values in Empirical Research; a Behavioralist Response. Midwest Journal of Political Science 14(1):71-104.

Searle, J. R. (1969) 'How to derive 'ought' from 'is'.” In The Is/Ought Question, edited by W.D. Hudson, pp. 120-134. New York: St. Martin”s.

Singer, Peter W. (2001/02) Corporate Warriors: The Rise of the Privatized Military Industry and Its Ramifications for International Security. International Security, 26(3):186-220.

Smith, Steve. (2002) The United States and the Discipline of International Relations: "Hegemonic Country, Hegemonic Discipline." International Studies Review 4(2):67-85. (2004) Singing Our World into Existence: International Relations Theory and September 11 (Presidential Address to the International Studies Association). International Studies Quarterly 48(3):499-515.

Somit, Albert and Joseph Tanenhaus. (1967) The Development of American Political Science from Burgess to Behavioralism. Boston: Allyn and Bacon.

Spegele, Roger. (1996) Political Realism in International Theory. Cambridge: Cambridge University Press.

Stedman-Jones, Sue. (1998) "Fact/Value." In Core Sociological Dichotomies, edited by Chris Jenks, pp. 49-62. London: Sage.

Steele, Brent J. (2007) Liberal-Idealism: A Constructivist Critique. International Studies Review 9:23-52.

Strauss, Leo. (1969) “What is Political Philosophy?” In Behaviouralism and Political Science, edited by Heinz Eulau, pp. 93-108. New York: Atherton Press.

Surkin, Marvin. (1970) "Sense and Non-Sense in Politics." In An End to Political Science: The Caucus Papers, edited by Marvin Surkin and Alan Wolfe, pp. 13-33. New York: Basic Books.

Surkin, Marvin and Alan Wolfe. (1970) "Introduction: An End to Political Science." In An End to Political Science: The Caucus Papers, edited by Marvin Surkin and Alan Wolfe, pp. 38. New York: Basic Books.

Taylor, Charles. (1967) "Neutrality in Political Science." In Philosophy, Politics and Society, Third Series, edited by Peter Laslett and W.G. Runciman, pp. 25-57. Oxford: Basil Blackwell.

Tickner, J. Ann. (2006) On the Frontlines or Sidelines of Knowledge and Power? Feminist Practices of Responsible Scholarship. International Studies Review 8:383-395. 
Tickner, J. Ann and Andrei P. Tsygankov. (2008) Responsible Scholarship in International Relations: A Symposium. International Studies Review 10:661-666.

Viotti, Paul R. and Mark V. Kauppi. (1987) International Relations Theory: Realism, Pluralism, Globalism. New York: Macmillan.

Waever, Ole. (1998) The Sociology of a Not So International Discipline: American and European Developments in International Relations. International Organization 52(4):687-727.

Waltz, Kenneth. (1986) "Reflections on Theory of International Politics: A Response to My Critics." In Neorealism and its Critics, edited by Robert O. Keohane, pp. 322-345. New York: Columbia University Press.

Weber, Max. (1949a[1917]) "The Meaning of 'Ethical Neutrality' in Sociology and Economics." In Max Weber on The Methodology of the Social Sciences, edited by E. A. Shils and H. A. Finch, pp. 1-47. Glencoe: Free Press (1949b[1904]) “'Objectivity' in Social Science and Social Policy." In Max Weber on The Methodology of the Social Sciences, edited by E. A. Shils and H. A. Finch, pp. 49-112. Glencoe: Free Press (2004[1918/1919]) The Vocation Lectures, edited by David Owen and Tracy Strong. London: Hackett

Widmaier, Wesley W. (2004) Theory as a Factor and the Theorist as an Actor: The "Pragmatist Constructivist" Lessons of John Dewey and John Kenneth Galbraith. International Studies Review 6:427-445.

Williams, Michael C. (2004) Why Ideas Matter in International Relations: Hans Morgenthau, Classical Realism, and the Moral Construction of Power Politics. International Organization, 58(4):633-665. 
${ }^{\mathrm{i}}$ An attempt to test the consistency among the epistemic, ontological, and normative propositions of Realist IR is found in Hamati-Ataya (2006).

${ }^{\text {ii }}$ I do not mean that Smith does not consider the ontological/epistemic dimensions of the problem, rather that the logic of his reasoning, which is guided by a properly ethical concern, determines the precedence of the problem of value-freedom, and that this precedence determines the sequence in which the other questions are posed.

iii This criterion is based on the idea that the means whereby knowledge is validated can be made independent of the logic of discovery itself, and therefore that methodological value-control can guarantee a certain measure of objectivity. For a critique of this view, see Bourdieu, Chamboredon and Passeron (1983[1968]).

iv Most Behavioralists adopted a positivist/scientist approach, grounded in the subject/object distinction, where objective knowledge derives exclusively from the qualities of the object, regardless of those of the subject.

${ }^{v}$ I am grateful to Professor Theodor Hanf for this important detail.

${ }^{\mathrm{vi}}$ A review of two leading IR journals - International Organization (IO) (Vol. 56-64) and International Security (IS) (Vol. 26-35) since "September 11" points to the marginal status of reflexive IR and its research and social concerns. Some exceptions are worth noting in $I S$, such as Katzenstein and Okawara (2001/02), Singer (2001/02), Jentleson (2002), and Desch (2007/08) and in IO, Acharya (2004), Ruhs and Chang (2004), Barnett and Duvall (2005), and Barnett (2009). Nonetheless, and except for Williams (2004), these contributions are not properly "reflexive" (they may address ideas, norms, and ethics as objects of study, but their analyses are not fundamentally committed to theory as constitutive of world politics) in comparison to what appears in journals like International Studies Review, Review of International Studies, Millennium, or even International Studies Quarterly (see bibliography).

${ }^{\text {vii }}$ See also the English School (Dunne, 1998), and Normative Theory (Frost, 1986; Cochrane, 1999).

${ }^{\text {viii }}$ A typical example of this shift is illustrated in the following, "Preliminary Definition": "But what is meant by fact and what is meant by value? It is important in this area to start with a simple definition that can help us in the discussion. A classic factual statement is "It is raining outside"”' (Stedman-Jones, 1998: 49-50, emphasis added).

${ }^{\text {ix }}$ It finds its roots in the debate between R.M. Hare and John R. Searle, and was recently explored by post-positivist IR under the influence of the works of (the later) Wittgenstein, Gadamer, and Habermas. E.g., Fierke (2002). 
${ }^{\mathrm{x}}$ Early sociological Positivism (Comte, Marx, Durkheim) viewed social institutions as both factual and normative realities, which crystallized, at any given time, the singular institutionalization of historical practices, and the normative order shaping their reproduction. From this perspective, Positivism was the critical thought of an era.

${ }^{x i}$ This process is common to both physical and social scientists, and should therefore not be easily disregarded by Positivist scholars who view the pure sciences as their deontological role-model. 